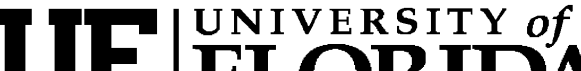 FLORIDA \\ IFAS Extension
}

\section{University of Florida Potato Variety Spot Light: Red LaSoda1}

\section{Chad M. Hutchinson, Doug Gergela, David Dinkins and Edsel Redden²}

General Comments: Red LaSoda is the red-skinned fresh market potato standard for Florida. Red LaSoda was observed in 1949 as a deep red mutant of LaSoda in the Louisiana potato breeding program. Originally, LaSoda was a selection from a cross of Triumph and Katahdin. Red LaSoda was released by the USDA and the Louisiana Agricultural Experiment Station in 1953. It has been in trials over many seasons and at many locations in Florida including university and grower sites. Production and quality results in this highlight sheet for Red LaSoda are summarized from the Red-Skinned, Fresh-Market trials conducted by the University of Florida over the past twelve seasons.

General Characteristics: Red LaSoda has a white to cream tuber flesh with a tuber shape of "round to oblong." It has a smooth, red to pink-colored skin with deep to intermediate eye depth. The variety has good yield potential and a relatively low specific gravity compared to other red-skinned potato varieties adapted for Florida production (Tables 1 and 2).
Season Length: The time from planting to vine kill is approximately 85-95 days for Red LaSoda depending on growing conditions during the season. Tuber size should be checked regularly late in the season. Plants should be vine killed when size distribution meets desired goals. The time from vine kill to harvest varies by season. At least two to three weeks should be allowed to mature and set tuber skin.

Fertilization and Growth: University trials have used approximately $200 \mathrm{lb}$ N/acre. Nitrogen in the Red LaSoda crop should be managed so that it "runs out" late in the season to improve tuber maturity and skin set. It may require less nitrogen than the UF/IFAS Extension general recommendation of 200 $\mathrm{lb}$ N/acre in heavier soils to achieve this goal. $\mathrm{P}$ and $\mathrm{K}$ should be applied based on soil tests.

Foliage develops rapidly with determinant growth resulting in early to mid-season maturity.

Planting: Tubers should break dormancy before planting. A seed piece of $21 / 2$ to $3 \mathrm{oz}$ is desired for planting. Plant spacing should be 5 to 8 inches in-row with 36 to 40 inches between rows. Closer in-row

1. This document is HS1078, one of a series of the Horticultural Sciences Department, Florida Cooperative Extension Service, Institute of Food and Agricultural Sciences, University of Florida. Original publication date July 25, 2006, reviewed and revised December 2009. Visit the EDIS Web Site at http://edis.ifas.ufl.edu.

2. Chad Hutchinson and Doug Gergela, Horticultural Sciences Department, University of Florida/IFAS; David Dinkins, St. Johns County Cooperative Extension Office; Edsel Redden, Putnam County Cooperative Extension Office, Institute of Food and Agricultural Sciences, University of Florida, Gainesville, 32611.

The Institute of Food and Agricultural Sciences (IFAS) is an Equal Opportunity Institution authorized to provide research, educational information and other services only to individuals and institutions that function with non-discrimination with respect to race, creed, color, religion, age, disability, sex, sexual orientation, marital status, national origin, political opinions or affiliations. U.S. Department of Agriculture, Cooperative Extension Service, University of Florida, IFAS, Florida A. \& M. University Cooperative Extension Program, and Boards of County Commissioners Cooperating. Millie FerrerChancy, Interim Dean 
spacing will reduce harvested tuber size. Excessive soil moisture late in the season will degrade lenticel appearance and delay skin set.

Diseases: Red LaSoda has general disease resistance characteristics. The variety is susceptible to scab, early blight, late blight, corky ring spot, and bacterial wilt. A standard extension recommended disease control program should be followed.

Seed Source: Open variety, available through many seed sources.

Other Information: Hutchinson, C.M., E.H. Simonne, G.J. Hochmuth, D.N. Maynard, W.M. Stall, S.M. Olson, S.E. Webb, T.G. Taylor and S.A. Smith. 2006. Potato production in Florida. In: Vegetable Production Guide for Florida. S.M. Olson and E.H. Simonne, eds. University of Florida.

Potato Association of America variety database: http://www.umaine.edu/PAA/Varieties/redlasoda.htm

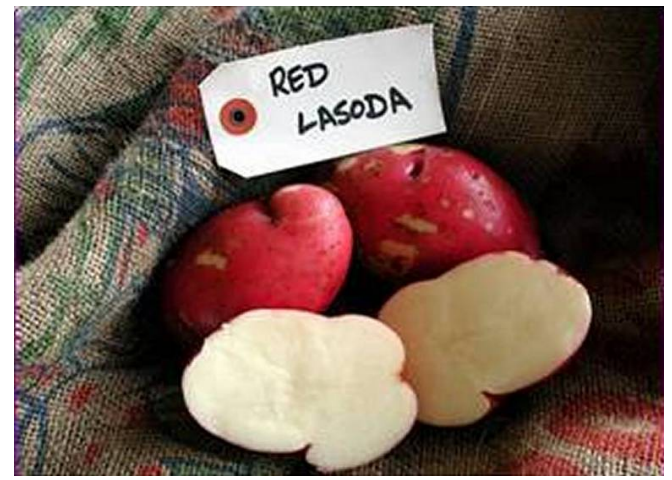

Figure 1. Typical tuber skin and internal flesh color of Red LaSoda. 


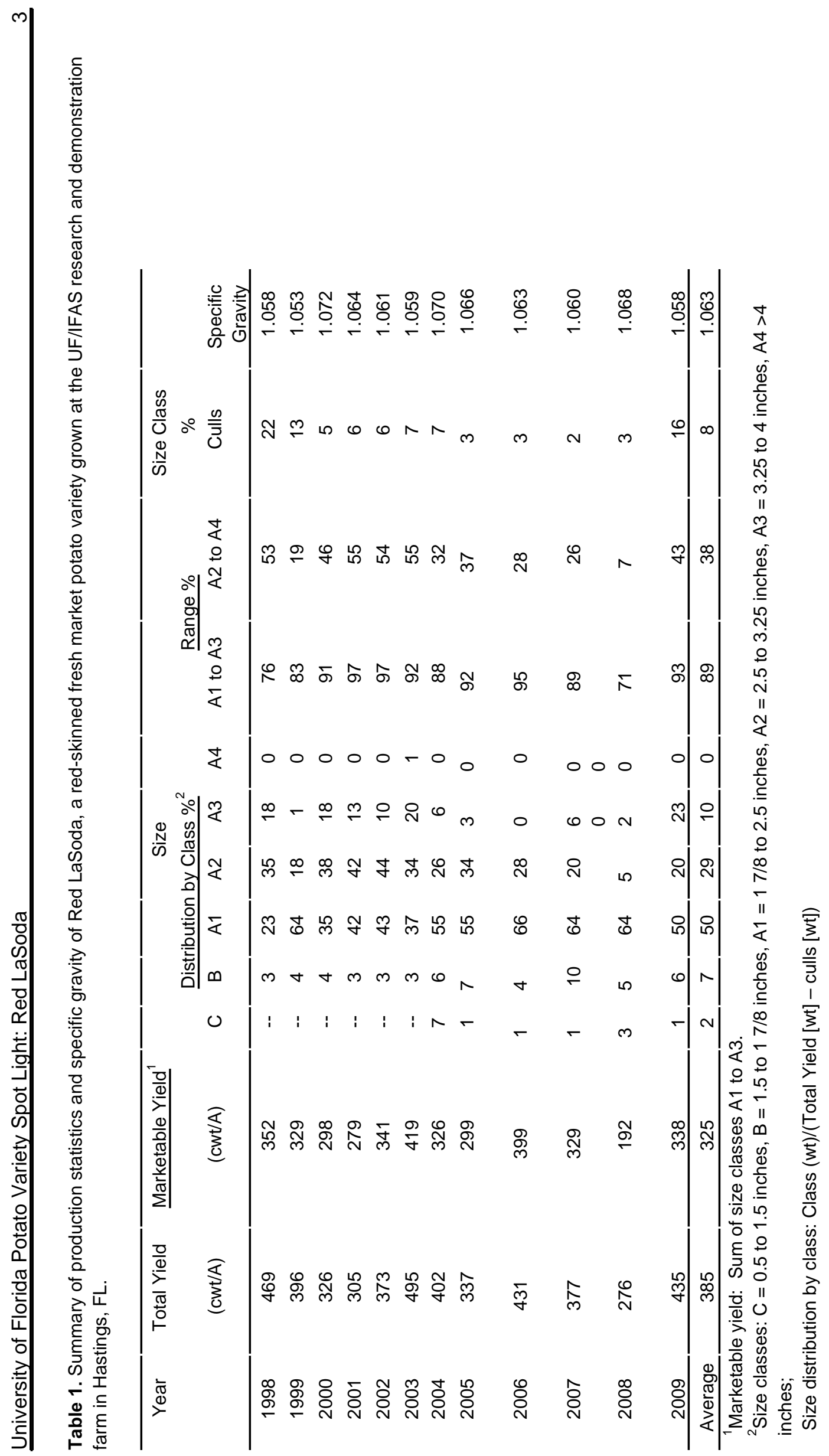




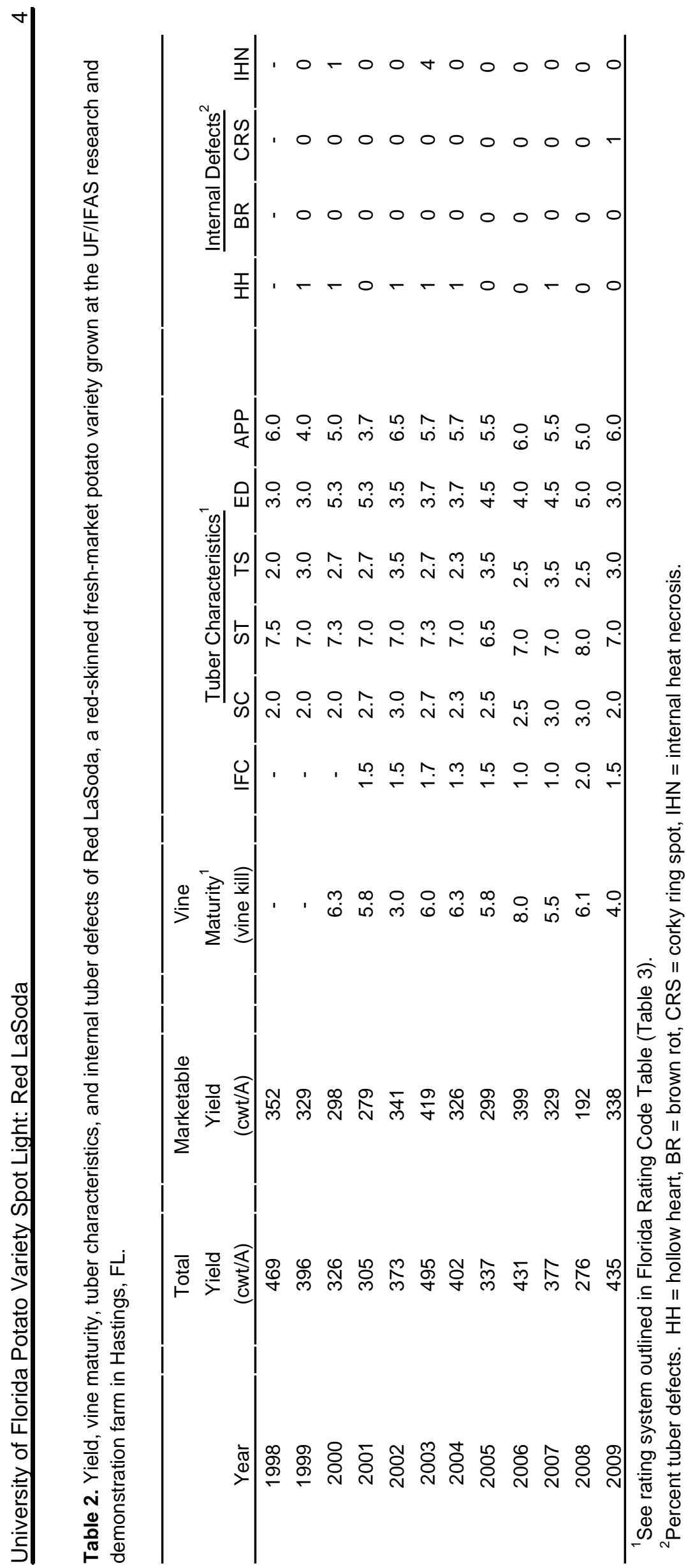




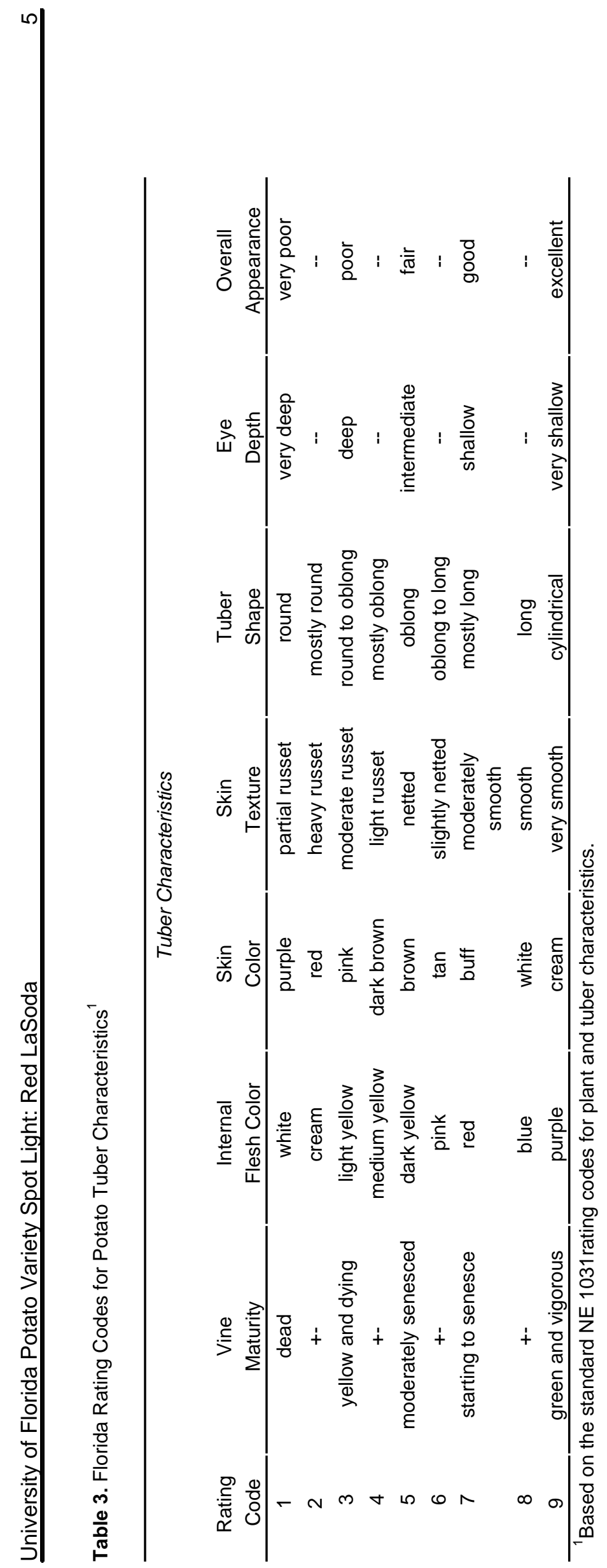

